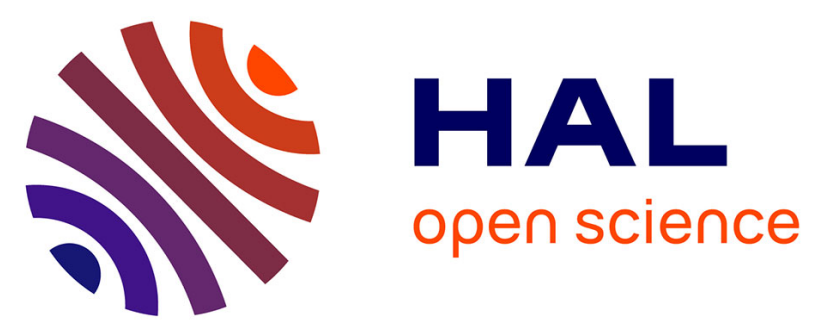

\title{
Expression of laccase IIIb from the white-rot fungus Trametes versicolor in the yeast Yarrowia lipolytica for environmental applications
}

\author{
Claude Jolivalt, Catherine Madzak, Agathe Brault, Eliane Caminade, \\ Christian Malosse, Christian Mougin
}

\section{To cite this version:}

Claude Jolivalt, Catherine Madzak, Agathe Brault, Eliane Caminade, Christian Malosse, et al.. Expression of laccase IIIb from the white-rot fungus Trametes versicolor in the yeast Yarrowia lipolytica for environmental applications. 2nd European Meeting in Oxizymes, Jun 2004, Naples, Italy. 2004. hal-01600125

\section{HAL Id: hal-01600125 \\ https://hal.science/hal-01600125}

Submitted on 4 Jun 2020

HAL is a multi-disciplinary open access archive for the deposit and dissemination of scientific research documents, whether they are published or not. The documents may come from teaching and research institutions in France or abroad, or from public or private research centers.
L'archive ouverte pluridisciplinaire HAL, est destinée au dépôt et à la diffusion de documents scientifiques de niveau recherche, publiés ou non, émanant des établissements d'enseignement et de recherche français ou étrangers, des laboratoires publics ou privés.

\section{다(1)(2)}

Distributed under a Creative Commons Attribution - ShareAlikel 4.0 International 
1'Laboratoire de Synthèse Sélective et Produits Naturels, UMR CNRS 7573, ENSCP, 11 rue Pierre et Marie Curie, 75231 Paris Cedex 05 2Laboratoire de Génétique Moléculaire et Cellulaire, UMR INRA/INA-PG, 78850 Thiverval-Grignon,

${ }^{3}$ Unité de Phytopharmacie et Médiateurs Chimiques, INRA, route de Saint-Cyr, 78026 Versailles Cedex, France, email: claude-jolivalt@enscp.jussieu.fr

\section{INTRODUCTION}

Fungal laccases (EC 1.10.3.2) are involved in lignin transformation,morphogenesis, pathogenesis and fungal virulence, as well as in the oxidation of numerous xenobiotics ${ }^{[1-3]}$

A wide range of their substrates are of environmental interest, and are recognized pollutants of waters and soils Laccases are potential useful tools to improve the chemical quality of polluted media through bioremediation ${ }^{[1,3]}$

Our objective is the design of laccases with:

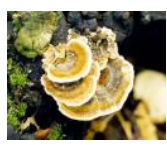

a high efficiency in catalysis (high redox potential)

a wider variety of substrates

a $\mathrm{pH}$ of activity optimized for natural media

Our approach is based on the knowledge of the cavity enclosing a weak reducing substrate of the enzyme, the arylamine 2,5-xylidine, and on the replacement of neighboring interacting residues

\section{RESULTS: Expression of LacIllb by Yarrowia lipolytica}

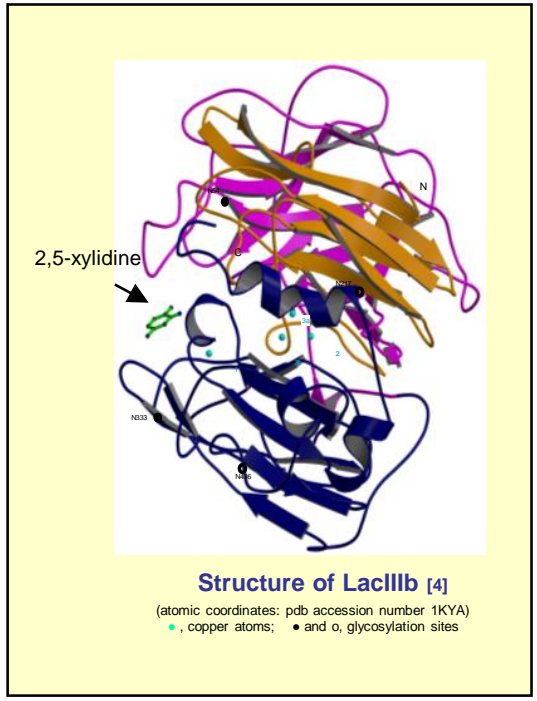

The gene encoding Laclllb has been cloned in Escherichia coli using the pGEM ${ }^{\circledR}-T$ plasmid

- It has been sequenced and comprises 1563 bases (sequence accession number AF414109), including a peptide signal

- It was then expressed in the yeast Yarrowia lipolytica using the pINA1269 vector (Patent INRA/INA-PG), thus allowing the production of an active form of the recombinant enzyme (transformation of the substrate ABTS to a green oxidized form on solid culture media and oxidation of guaïcol after electrophoretic separation). After tryptic digestion of the transformed $Y$. lipolytica extract, the mass spectrum contains the most significative ions detected and assigned to T. versicolor laccase peptides.

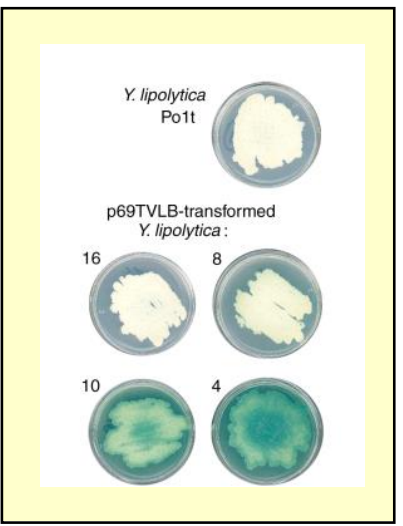

Laccase activity detection on agar plates assay. Numbers refer to different transformant clones of $Y$.

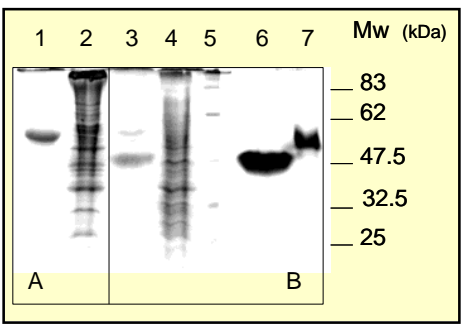

Electrophoresis analysis of recombinant laccase IIlb. [A] Samples were boiled before loading on the gel. Lane 1 - Laccase IIIb from T. versicolor. Lane 2 - Concentrated crude cell free extract from transtormant (clone 4) of Yarrowia lipolytica expressing laccase lilb. Laccase Illb from $T$. versicolor. Lanes 4 and 7 - Concentrated crude cell free extract from a transformant (clone 4) of Yarowi lipolytica expressing laccase llb 5 ane 5 - Molecular weight markers.

50). Laccase activity

.

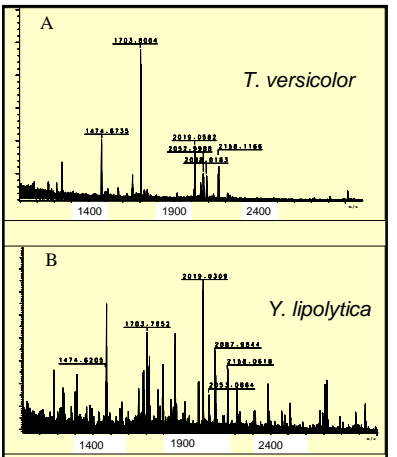

MALDI-TOF spectra

[A] Laccase Illib from $T$. versicolor.

[B] Analysis of the band corresponding to the activity detected in electrophoresis pattern of crude supernatant from a p69TVLB-derived transformant (clone 4) of Yarrowia lipolytica expressing laccase IIIIb.

\section{APPLICATION: Towards the engineering of fungal laccases}

1- T1 site and neighboring 2,5-xylidine ligand

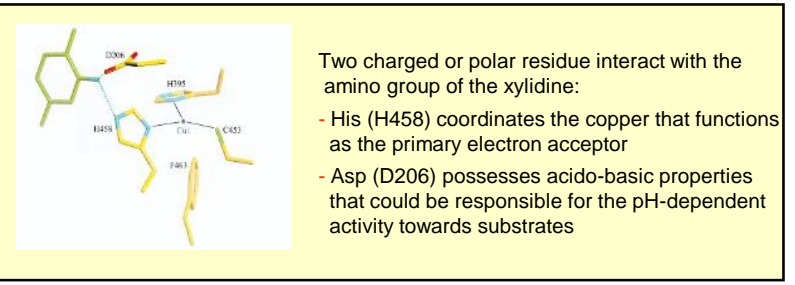

3- Strategy of directed mutagenesis
2 - Sequence alignment of laccases from fungi and higher plants

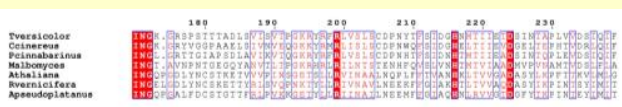

Biological roles of laccases from fungi and higher plants appear to be opposite: fungal laccases are involved in ligninolysis whereas enzymes from plants catalyze the initial polymerization of monolignols during lignification

-Fungal laccases have a negatively charged residue at the 206 position (Asp, D or Glu, E), whilst those of higher plants have an asparagine (Asn, $\mathrm{N}$ )

Higher plants: Athaliana $=$ Arabidopsis thaliana; Rvernicifera $=$ Rhus vernicifera; Apeudoplatanus $=$ Acer pseudoplatanus
Three mutants have been obtained comprising: a residue with another negative chain: D206E a residue with a polar uncharged chain: D206N a residue with an uncharged chain: D206A

-Their catalytic properties are currently studied.
References
[1] C. Jolivalt, S. Brenon, E. Caminade, C. Mougin, M. Pontié (2000) Immobilization of laccase from Trametes versicolor on a modified PVDF microfiltration membrane: characterization of the grated support and application in removing a phenylurea pesticide in wastewater, J. Membrane Sci. 180:103-113.

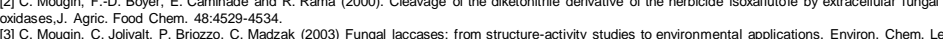
[3] C. Mougin, C. Jolivalt, P. Briozzo, C. Madzak (2003) Fungal laccases: from structure-activity studies to environmental applications. Environ. Chem. Lett. 1:145-148. [4] T. Berrand, C. Jolivalt, P. Briozzo, E. Caminade, N. Joly, C. Madzak and C. Mougin (2002) Crystal structure of a four-copper laccase complexed with an
arylamine: insights into substrate reconnition and correlation with kinetics, Biochemistry 41:7325-7333 